\title{
EMPATI REMAJA TERHADAP KORBAN BULLYING DI PEKANBARU
}

\author{
Raja Rahima M.R.A., Zaitun \\ Universitas Islam Negeri Sultan Syarif Kasim Rian \\ raja.rahima.mra@uin-suska.ac.id \\ zaitun.syahbudin@yahoo.com
}

\begin{abstract}
Abstrak : Penelitian ini bertujuan untuk melihat gambaran rasa empati siswa terhadap korban bullying. Subjek penelitian ini berjumlah 30 orang dari lima sekolah di Kecamatan Lima Puluh Kota Pekanbaru. Data diperoleh melalui angket terbuka dan diolah dengan skoring 1-5. Deskripsi data menggunakan kriterium dan interval data. Hasil penelitian menunjukkan rasa empati siswa terhadap korban bullying berada pada kategori tinggi. Kemungkinan penyebab bullying adalah faktor lain dan disarankan melakukan penelitian lanjutan dengan subjek penelitian yang lebih besar.
\end{abstract}

Kata Kunci: Rasa Empati, Siswa, Korban Bullying.

\section{PENDAHULUAN}

Sekolah adalah tempat bagi remaja menghabiskan sebagian besar waktu mereka dalam keseharian. Dimulai dari pagi hingga sore hari. Dalam rentang waktu selama itu, sekolah menjadi tempat bagi mereka menemukan nilai-nilai kehidupan lebih banyak dibanding di rumah atau di lingkungan lainnya. Seharusnya sekolah menjadi tempat didikan nilai yang paling baik bagi mereka karena di lengkapi dengan sarana dan prasarana yang baik, pendidik yang tersertifikasi, pendidik yang berlatabelakang sarjana yang menguasai ilmu pedagogik, anak-anak yang juga terdidik setiap harinya, namun belakang ini, sekolah memiliki masalah yang sangat serius, yaitu bullying.

Bullying menurut Coloroso dalam Fatia Aldiana (2017:42) adalah intimadasi yang dilakukan pihak yang lebih kuat terhadap pihak yang lebih lemah. Beberapa bentuk intimidasi yang dapat dikategorikan bullying menurut Saripah (2010) yaitu: (1) Pusposeful yaitu kesengajaan dengan maksud menyakiti (2) Imbalance yaitu ketidakseimbangan baik dalam hal kekuatan, kekayaan, maupun fisik, dan (3) Continual yaitu perbuatan yang dilakukan terus-menerus. Fakta yang dapat kita lihat, seringkali siswa di sekolah menjadikan beberapa teman mereka sebagai korban yang terus diintimidasi baik berupa tindakan fisik seperti memukul, tindakan pengasingan ataupun dengan verbal yang menyakitkan. Meskipun kadangkala mereka tidak melakukan hal tersebut terus-menerus, namun mereka melakukannya dengan kesadaran dan berniat menyakiti korban. 
Kasus bullying baru-baru ini yang terjadi di Tangerang Selatan adalah satu contoh dari ribuan kasus kekerasan di sekolah oleh teman sebaya pada 20 September 2017 lalu (KOMPAS.com). Kasus ini melibatkan ketidakseimbangan kekuatan yaitu anak-anak SMA yang melucuti pakaian anak SMP di lapangan terbuka. Intimidasi seperti ini tentu bukan kekerasan fisik namun berdampak sangat hebat bagi psikologis korban. Kasus lainnya adalah empat orang siswa SMPN Ciriwangin (KOMPAS.com) yang menjadi korban bullying lima siswa lainnya pada 27 Agustus 2017 lalu, kejadian ini disertai dengan kekerasan fisik. Kejadian ini bahkan direkam dan tersebar di dunia maya melalui aplikasi gadget. Kasus-kasus seperti ini tentu sangat berbahaya bagi siswa.

Bullying dapat berdampak negatif terhadap emosional dan fisik siswa. Dampak emosional seperti: takut, terasing, malu, dipresi, tidak berdaya, sakit hati, sedih, bodoh, diperlakukan tidak manusiawi, merasa diinjak-injak, jelek, dan tidak berguna. Sedangkan dampak terhadap fisik yaitu: bekas gigitan, memar, luka, patah tulang, geger otak, mata rusak, kerusakan otak permanen, dan dampak yang paling serius adalah bunuh diri (Sullivan, 2000). Berdasarkan seriusnya dampak yang mungkin dialami oleh korban bullying, perlu dipahami faktor penyebab terjadinya bullying.

Ditelusuri penyebab bullying salah satunya adalah tontonan yang tidak mendidik yang mereka dapat melalui media internet baik melalui youtube, Instagram, dan facebook. Hal ini terjadi karena kemajuan teknologi dan akses internet yang begitu mudah tidak diiringi dengan pengawasan orangtua. Apabila terus dibiarkan hal ini akan menimbulkan pola perilaku masyarakat yang tidak sehat serta gangguan psikologis bagi korban bullying. Asumsi berikutnya adalah, bahwa bullying dalam dunia pendidikan diakibatkan oleh buruknya sistem dan kebijakan pendidikan yang berlaku. Misalnya muatan kurikulum yang hanya mengandalkan kemampuan kognitif dan mengabaikan pendidikan afektif sehingga mereka kehilangan nilai-nilai persahabatan dan kemanusiaan antara lain adalah perasaan berempati kepada sesama.

Menurut Keen S. dalam Ioannidou F. dan Konstantikaki V. (2008) empati adalah kemampuan untuk mengenali perasaan orang lain, yang menyebabkan perasaan sama, dan ikut serta dalam pengalaman emosional individu tanpa menjadi bagian dari kondisi tersebut. Empati pada dasarnya dimiliki semua manusia, dan menjadi faktor penting dalam pembentukan perilaku seseorang. Manusia yang memiliki empati pada orang lain tentu tidak mudah menyakiti sesama karena akan memikirkan dampak perilaku tersebut jika dia juga mengalami hal yang sama. Perasaan empati pada dasarnya dimiliki oleh semua manusia, namun perlu diasah untuk tetap peka terhadap penderitaan orang lain. Asumsi awal penelitia adalah siswa yang melakukan bullying karena mereka tidak memiliki perasaan empati yang cukup untuk memahami perasaan orang lain. Berdasarkan asumsi tersebut maka peneliti melakukan penelitian dengan judul "Gambaran Rasa Empati Siswa terhadap Korban Bullying di SMP Se-Kecamatan Lima puluh Kota Pekanbaru”.

Penelitian ini dilakukan terhadap 30 orang siswa dari lima sekolah yang berada di tengah kota Pekanbaru yaitu SMPN 04, SMPN 05, SMPN 10, SMPN 14 dan SMP AlIshlah. Lokasi ini dipilih berdasarkan analisis situasi atau studi awal pada Bulan Maret 2017, peneliti menemukan anak-anak di wilayah ini menyaksikan banyak kasus bullying di sekolah mereka pada tingkatan kekerasan verbal, dan beberapa kasus kekerasan fisik.

Penelitian ini berjenis deskriptif kuantitatif dengan tujuan penelitian untuk melihat gambaran rasa empati siswa terhadap korban bullying. Instrumen yang digunakan adalah angket terbuka. Skor yang diberikan kepada jawaban siswa terendah 1 dan tertinggi 5, data 
dideskripsikan melalui kriterium (Syaiful Azwar, 2003:22) dan interval data (Agus Irianto, 2010:22).

Adapun penelitian terdahulu untuk kasus bullying antara lain: Siswati dan Coastrie Ganes Widayanti dari Fakultas Psikologi Universitas Diponegoro Semarang pada tahun 2009 meneliti tentang Fenomena Bullying di Sekolah Dasar Negeri di Semarang. Sedangkan Nissa Ardilla dari Departement Kriminologi FISIP Universitas Indonesia pada tahun 2009 meneliti tentang Pengaruh Kontrol Sosial terhadap Perilaku Bullying Pelajar di Sekolah Menengah Pertama. Kemudian Rina Mulyani dari Fakultas Dakwah dan Komunikasi Universitas Islam Negeri Sunan Kalijaga Yogyakarta pada tahun 2013 meneliti tentang Pendekatan Konseling Spiritual untuk Mengatasi Bullying (Kekerasan) Siswa.

\section{HASIL}

Penelitian ini menunjukkan gambaran rasa empati siswa terhadap korban bullying sebagai berikut:

\begin{tabular}{clcc}
\hline $\begin{array}{c}\text { Interval } \\
\text { Data }\end{array}$ & Kriteria & F & \% \\
\hline $\mathbf{2 5 - 2 9}$ & Sangat Tinggi & 4 & 13.3 \\
$\mathbf{2 0 - 2 4}$ & Tinggi & \multicolumn{1}{c}{} & \\
& & 8 & \\
$\mathbf{1 5 - 1 9}$ & Sedang & 8 & 26.7 \\
$\mathbf{1 0 - 1 4}$ & Kurang & 0 & 0 \\
$\mathbf{5 - 9}$ & Rendah & 0 & 0 \\
\hline
\end{tabular}

Berdasarkan olah data terlihat siswa memiliki rasa empati yang tinggi atau positif tentang empati kepada korban bullying. Data ini berdistribusi normal jika dilihat dari skor yang diperoleh oleh siswa sebagai subjek penelitian dan jumlah subjek memenuhi syarat penggunaan instrumen angket.

\section{PEMBAHASAN}

Penelitian ini menunjukkan bahwa gejala yang tampak pada studi awal bukan karena kurangnya empati pada diri siswa. Frekuensi untuk kriteria tinggi pada interval data 20-24 lebih besar dari kriteria lainnya. Meskipun tidak banyak frekuensi skor siswa pada kriteria sangat tinggi, namun kriteria ini sudah cukup bagus untuk mereka. Data ini menolak asumsi awal penelitian yaitu bullying yang terjadi di sekolah-sekolah Kecamatan Lima Puluh Kota Pekanbaru karena kurangnya rasa empati, hal ini mengindikasikan faktor lain sebagai penyebab terjadinya beberapa tindakan bullying.

Menurut Beane (2008) beberapa faktor yang dapat menyebabkan bullying yaitu: pengaruh fisik, faktor biologis, temperamen, pengaruh lingkungan sosial, keinginan 
mempelajari, kepercayaan terhadap superioritas sendiri, kekerasan, agresi, dan komplik di media, kekerasan dalam olahraga, prasangka, kecemburuan, melindungi citra diri, ketakutan, Egois, kurang sensitif, dan keinginan untuk diperhatikan, Mentalitas kelompok, Lingkungan keluarga yang miskin, Kurangnya pemahaman tentang bullying, Harga diri yang rendah, Reaksi terhadap ketegangan, Melihat tindakan agresi dan diberi reward, Keinginan untuk mengontrol dan berkuasa, Lingkungan dan nilai-nilai masyarakat yang buruk, Lingkungan sekolah yang buruk.

Penyebab-penyebab di atas mungkin menjadi alasan lain terjadinya bullying. Berdasarkan hasil penelitian ini, perlu diadakan penelitian lanjutan dengan subjek penelitian yang lebih banyak dan representatif untuk mendapatkan gambaran yang tepat.

\section{SIMPULAN}

Hasil penelitian ini menunjukkan gambaran rasa empati siswa SMPN Se-Kecamatan Lima Puluh Kota Pekanbaru terhadap korban bullying berada pada katergori tinggi. Hasil penelitian ini mengindikasikan faktor lain sebagai penyebab terjadinya bullying di SMPN Sekecamatan Lima Puluh Kota Pekanbaru.

\section{REFERENSI}

Agus Irianto. 2010. Statistik Konsep Dasar, Aplikasi dan Pengembangannya. Jakarta: Kencana Prenada Media Group.

Beane, A. L. 2008. Protect Your Child from Bullying. San Fransisco: Jossey-Bass.

Fatian Aldiana. 2017. Efektivitas Layanan Bimbingan Kelompok Menggunakan Metode Sosiodrama untuk Meningkatkan Pemahaman Siswa tentang Bulying. Tesis. Padang: UNP Press.

Ioannidou F. \& Konstantikaki V. 2008. Empathy and Emotional intelligence: What is it Really About?. International Journal of Caring Science. Vol. 1 No. 3. Diakses pada 15 Maret 2017.

Megapolitan.kompas.com. Diakses pada November 2017.

Nissa Ardilla. 2009. Jurnal Kriminologi Indonesia: Pengarub Kontrol Sosial Terhadap Perilaku Bullying Pelajar Di Sekolah Menengah Pertama. Jakarta: Kriminologi Fisip Universitas Indonesia.

Saripah. 2010. Model Kognitif-Perilaku untuk Menanggulangi Perilaku Bullying Model Konseling untuk Korban Bullying pada Siswa Sekolah Dasar. Disertasi tidak diterbitkan. Bandung: Sekolah Pascasarjana Universitas Pendidikan Indonesia.

Siswati \& Coastrie Ganes Widayanti. Fenomena Bullying di Sekolah Dasar Negeri di Semarang:Sebuah Studi Deskriftif. Jurnal Psikologi UNDIP. Vol.5 No. 2. Diakses pada 21 Maret 2017 pada Situs eprint.undip.ac.id/8336/.

Sullivan, K. 2000. The Anti-Bullying Handbook. Auckland: Oxford University Press.

Syaiful Azwar. 2003. Penyusunan Skala Psikologis. Yogyakarta: Pustaka Pelajar. 